\title{
Evaluation of Inhaled Corticosteroid Efficacy by Electron Microscopy in Patients with Chronic Obstructive Pulmonary Disease
}

\author{
Kronik Obstriiktif Akciğer Hastalı̆̆ı Olan Hastalarda İnhale \\ Kortikosteroidlerin Etkinliğinin Elektron Mikroskopisi ile \\ Değerlendirilmesi
}

\author{
Çağla Pınar Taştan ${ }^{1}$, Kadriye Mine Erbil², Gülay Ulusal Okyay³, Sadık Ardıç4 \\ ${ }^{1}$ Clinic of Chest Disease and Tuberculosis, Gaziosmanpaşa Hospital, İstanbul \\ ${ }^{2}$ Department of Anatomy, Faculty of Medicine, Hacettepe University, Ankara \\ ${ }^{3}$ Department of Nephrology, Faculty of Medicine, Gazi University, Ankara \\ ${ }^{4}$ Clinic of Chest Disease and Tuberculosis, Dışkapı Yıldırım Beyazıt Education and Research Hospital, Ankara
}

\begin{abstract}
Objective: Inhaled corticosteroids definitely alleviate bronchial mucosal inflammation in patients with asthma. Nevertheless, the data regarding their anti-inflammatory effects in patients with chronic obstructive pulmonary disease (COPD) is controversial. The aim of the present study is to assess the efficacy of inhaled corticosteroids in reduction of inflammatory response in patients with COPD.
\end{abstract}

Methods: A total of 14 subjects with the new diagnosis of mild to moderate COPD (forced expiratory volume in one second $\left[\mathrm{FEV}_{1}\right]$ $>50 \%$ of predicted value) were prospectively enrolled. Endobronchial sampling with bronchoscopic intervention was performed before and after three months of treatment with inhaled fluticasone propionate (FP) (500 $\mu \mathrm{g}$ twice daily). Histopathological evaluations were performed with electron microscopy and the anti-inflammatory effects of the medicine were evaluated. Differences in arterial blood gas analysis and pulmonary functions were also investigated.

Results: Three months treatment with FP revealed regression of the epithelial edema, decrease in the thickness of basal lamina, augmentation of the cilliary structures, reduction in the number of macrophages and lymphocytes in biopsy samples. Significant improvement of pulmonary functions was remarkable in spirometric test results. The difference in arterial blood gas analyses was not significant.

Conclusion: Treatment with FP provided significant anti-inflammatory effects on endobronchial tissue samples and remarkable improvement in pulmonary functions in patients with COPD.

Keywords: Chronic obstructive pulmonary disease, inhaled corticosteroid, anti-inflammatory effect, electron microscopy

\section{ÖZET}

Amaç: İnhale kortikosteroidler, astımlı hastalarda bronşiyal mukozal inflamasyonu azaltırlar. Ancak, kronik obstruktif akciğer hastalığ (KOAH) olan hastalarda anti-inflamatuar etkinlikleri hakkındaki bilgiler tartışmalıdır. Bu çalışmanın amacı, KOAH'lı hastalarda, inhale kortikosteroidlerin inflamatuar cevabın azaltılmasında etkinliklerinin değerlendirmesidir.

Yöntemler: Hafif-orta düzeyde yeni başlangıçlı KOAH tanısı konmuş 14 hasta (1. saniyede zorlu ekspiratuar volumü $\left[\mathrm{FEV}_{1}\right]>$ beklenen değerin \%50'si) prospektif olarak değerlendirmeye alındı. Tüm hastalardan, üç aylık inhale flutikason propionat (günde 2 kez; $500 \mu \mathrm{g}$ ) tedavisi öncesi ve sonrasında bronkoskopik inceleme ile endobronşiyal örneklemeler yapıldı. Histopatolojik inceleme elektron mikroskopisi ile gerçekleştirildi ve uygulanan tedavinin anti-inflamatuar etkileri değerlendirildi. Aynı zamanda, hastaların arter kan gazları ve pulmoner fonksiyonlarındaki değişiklikler de incelendi.

Bulgular: İnhale flutikason propionat ile üç aylık tedavinin sonucunda, epitel ödeminin gerilediği, bazal lamina kalınlığının azaldığı, siliyer yapılarda iyileşmenin meydana geldiği, makrofaj ve lenfosit sayılarının belirgin olarak azaldığı gözlendi. Pulmoner fonksiyonların spirometri ile değerlendirmesinde anlamlı düzelme saptanırken, arter kan gazı analizlerinde farklılık izlenmedi.

Sonuç: İnhale flutikason propionat tedavisi ile KOAH'lı hastaların endobronşiyal örneklerinde anlamlı anti-inflamatuar etkiler ve pulmoner fonksiyonlarında belirgin düzelmeler sağlanmıştır.

Anahtar Kelimeler: Kronik obstrüktif akciğer hastalığı, inhale kortikosteroid, anti-inflamatuar etki, elektron mikroskopisi

Received date / Alındığı tarih: 01.11.2012; Accepted date / Kabul tarihi: 15.03.2013 Available online date / Çevrimiçi yayın tarihi: 20.09.2013

Address for correspondence / Yazışma adresi: Çağla Pınar Taştan, Clinic of Chest Disease and Tuberculosis, Gaziosmanpaşa Hospital, Gaziosmanpaşa, İstanbul, Turkey; E-mail: caglapinar75@yahoo.com.tr

(C) Telif hakk1 2013 Türkiye Solunum Araştırmaları Derneği (TÜSAD) • C Copyright 2013 Turkish Respiratory Society (TRS)

Solunum 2013; 15(3):149-154 • DOI: 10.5152/solunum.2013.030

Makalelerin tam metinlerine www.solunum.org.tr/dergi adresinden ulaşabilirsiniz. • Available online at www.solunum.org.tr/dergi 


\section{INTRODUCTION}

Chronic obstructive pulmonary disease (COPD) is characterised by persistent airflow limitation which is usually progressive and associated with an enhanced chronic inflammatory response in the airway and lung to noxious particles or gases (1). In addition to cigarette smoking as the primary cause; genetic factors, airway hypersensitivity, occupational exposures, environmental pollution, socioeconomic situation and recurrent bronchopulmonary infections have also been implicated in the etiology of COPD $(1,2)$. The increasing mortality and morbidity related to COPD establish the disease as a serious global health issue (3). The efficacy of inhaled corticosteroids in the treatment of COPD still remains controversial, although their usage in asthma is well defined (4-6).

The purpose of this study was to examine whether an inhaled corticosteroid treatment provides an anti-inflammatory benefit in patients with COPD. Our hypothesis was that patients with COPD would have selective anti-inflammatory benefits at a cellular level and they would also have functional and clinical improvements.

\section{METHODS}

Patients were prospectively recruited from the outpatient clinic of Chest Diseases and Tuberculosis Department. The study was approved by the local ethics committee and conducted in accordance with the Helsinki declaration. All participants gave written informed consent.

Fourteen consecutive patients with a new diagnosis of mild to moderate COPD according to the Global Initiative for Chronic Obstructive Lung Disease (GOLD) guideline were included (1). Patients were in a stable period (without acute exacerbation symptoms for at least four weeks) and had $\mathrm{FEV}_{1}$ values improved less than $15 \%$ or $200 \mathrm{~mL}$ following an inhaled short acting bronchodilator. All were current or ex-smokers. The patients on systemic or inhaled steroid therapy with the history of asthma or atopia, and patients with other active lung diseases or psychiatric diseases were excluded. Spirometry with a short acting bronchodilator and arterial blood gas analyses were performed. Following the baseline bronchoscopy (Olympus VES, Tokyo, Japan), inhaled fluticasone proprionate (FP); $500 \mu \mathrm{g}, 2$ times a day was started and participants were invited monthly for control visits.

The bronchoscopic biopsy samples taken before and after the treatment were evaluated by electron microscopy (Jeol JEM 1200EX transmission). Following 24 hours fixation, the specimens were washed out with Sorenson's phosphate buffer. Postfixation was performed by $1 \%$ osmium tetroxide for one hour. The specimens were serially dehydrated with alcohol, conducted with propylene oxide and blocked by using araldite CY 212. 1-2 micron sections were taken and stained with methylene blue, examined by light microscopy and thin sections with 60-90 nanometer were taken with an ultratome from selected areas. These sections were contrasted with uranyl acetate and lead citrate. Ultimately, prepared samples were examined by electron microscopy at a magnification of $\mathrm{x} 2500$ and images were obtained. Since the mesh numbers of biopsy samples were not equal, the total count for one cell type was divided to an overlocked mesh count and thus the results were standardized.

\section{Assesment of Response to Treatment}

The response to the steroid treatment was defined by the comparison of $\mathrm{FEV}_{1}$ of baseline and post-treatment values ( $\%$ of predicted values). The $\mathrm{FEV}_{1}$ difference was calculated by substracting the post treatment $\mathrm{FEV}_{1}$ value from the baseline $\mathrm{FEV}_{1}$ value. An $\mathrm{FEV}_{1}$ difference, smaller than zero was accepted as response to the treatment. An $\mathrm{FEV}_{1}$ difference, equal to or greater than zero was defined as no response to the treatment.

\section{Statistical Analyses}

The statistical analysis of the trial was performed by Statistical Package for Social Sciences software (SPSS, 11.0 version). We used Wilcoxon Signed Rank Test for the comparisons within the groups and Mann-Whitney U test between the groups. Data were presented as median (IQR-interquartilerange). Two sided $p$ value of $<0.05$ was considered as significant. The comparisons were made between the groups with and without response to the treatment.

\section{RESULTS}

Fourteen male patients were enrolled for the study. Mean age was $59.28 \pm 11.53$ years and the mean pack years of smoking was $42.64 \pm 21.94$ years.

No significant difference was detected between the arterial blood gas analyses at baseline and after the treatment. However, significant improvement with FP treatment was established at all spirometric parameters, except forced vital capacity (FVC) (lt) $(\mathrm{p}<0.05)($ Table 1).

Table 1. The comparison of arterial blood gas analyses and pulmonary function testing before and after treatment

\begin{tabular}{lccc}
\hline \hline & $\begin{array}{c}\text { Before Treatment } \\
\text { n:14 }\end{array}$ & $\begin{array}{c}\text { After Treatment } \\
\text { n:14 }\end{array}$ & $\begin{array}{c}\mathbf{p} \\
\text { value }\end{array}$ \\
\hline $\mathrm{SaO}_{2}$ & $93.50(89.33-95.00)$ & $95(90.05-95)$ & 0.799 \\
$\mathrm{PaO}_{2}$ & $72.80(61.35-75.50)$ & $74.20(58.55-77.25)$ & 0.754 \\
$\mathrm{PaCO}_{2}$ & $37.10(35.80-40.25)$ & $38.10(35.15-39.25)$ & 0.722 \\
$\mathrm{FEV}_{1}$ (It) & $1.77(1.40-1.96)$ & $1.99(1.78-2.30)$ & 0.016 \\
$\mathrm{FEV}_{1}(\%)$ & $56.40(51.75-64.05)$ & $67.75(60.48-76.05)$ & 0.019 \\
$\mathrm{FVC} \mathrm{(It)}$ & $3.03(2.39-3.15)$ & $3.09(2.66-3.27)$ & 0.084 \\
$\mathrm{FVC} \mathrm{( \% )}$ & $71(64.50-79.30)$ & $77.55(69.38-88.45)$ & 0.048 \\
$\mathrm{FEV}_{1} / \mathrm{FVC}$ & $62.30(58.53-66.88)$ & $68.40(63-72.48)$ & 0.013 \\
\hline
\end{tabular}

Data were expressed as median (IQR-interquartile range).

$\mathrm{SaO}_{2}$ : arterial oxygen saturation, $\mathrm{PaO}_{2}$ : partial oxygen pressure, $\mathrm{PaCO}_{2}$ : partial carbon dioxide pressure, $\mathrm{FEV}_{1}(\mathrm{It})$ : forced expiratory volume in one second, It: in liters, $\%$ : per cent predicted, FVC: forced vital capacity 
Three mucosal biopsy samples were obtained from the carinae of bronchi of the right middle and lower lobes before and after the treatment. At baseline specimens; epithelium was not intact and the communicating units between the cells were degenerated (Figure 1a). Edema was prominent and the ciliary structures were distorted, even lost in some specimens (Figure 1b). The goblet cells were numerous and increased in volume, causing increased mucus production. The mitochondria appeared normal ultrastructurally. Halo formation around the nuclei of some cells suggested apoptosis. The basal lamina appeared to be increased in thickness $(422 \pm 47.05 \mathrm{~nm}$ ) (Figure 1C). Beneath the basal lamina at subepithelial connective tissue, infiltration of intensive inflammatory cells were remarkable and the prominent cells were macrophages with marked phagolysosomes indicating their increased activity. In connective tissue, the main active cells were fibroblasts. Around the fibroblasts there were dispersed collagen fibers. At the tunica muscularis, muscle cell proliferation was observed. The vessel endothelium was smooth.

After the inhaled corticosteroid therapy; the surface epithelial cells appeared intact and more regular in shape with less edema (Figure 2a). The ciliary structures were improved to a considerable extent. In some specimens, intensive ciliary formations were remarkable (Figure $\mathbf{2 b}$ ). The number of goblet cells were diminished. However, they were still large in volume. Intracytoplasmic organelles were clearly visible. The halo formations around the nuclei of some cells in the baseline samples were missing. The thickness of basal lamina was decreased to $397 \pm 49.26 \mathrm{~nm}(\mathrm{p}<0.005)$ (Figure 2c). In the subepithelial area inflammatory cell infiltration was diminished. The collagen fibers appeared more regular. There were no alteration in muscle cell proliferation in the bronchial tunica muscularis. The vessel endothelium appeared smooth.

The cell counts (number/mesh) were summarised in Table 2. The majority of the counted cells were fibroblasts. The number of neutrophils were lower than the number of other cells, in reverse to expectations. The comparison of baseline and post-treatment values of cell counts revealed declines in the numbers of all cell types except basophils. However, only the reduction in the number of macrophages and lymphocytes were significant $(p<0.05)$ and the reduction in macrophage number was in correlation with an improvement in the $\mathrm{FEV}_{1}(\%$ of predicted value) (Figure 3$)$.

\section{DISCUSSION}

The presented study showed that in patients with mild to moderate COPD, three months treatment of inhaled corticosteroid provided anti-inflammatory effects over the bronchial mucosa exhibited by electron microscopy and significant improvement over the pulmonary functions revealed by spirometric testing. These findings point out the constructive effects of the therapy in this particular patient population.

It was widely known that, as the principle defence cells of the lower airways, the macrophages increase in number after exposure to cigarettee smoke and contribute to the pathogenesis of COPD by secreting various substances $(7,8)$. In our baseline biopsy samples, macrophages were the predominating cells with increased phagolysosomes similar to the previously reported trials $(9,10)$. We manifested a significantly reduced number of macrophages after corticosteroid treatment in correlation with improvement in $\mathrm{FEV}_{1}$ (\% of predicted values). In like manner, it was pointed out in several studies that lymphocytes have important roles in the pathogenesis of COPD $(9,11)$. Our results also showed a markedly reduced number of the lymphocytes after the therapy. In the literature, there are contradictory results about the alterations in the number of neutrophils after inhaled steroid treatment (12-14). We manifested a reduction in the number of neutrophils as a result of the treatment. However, this reduction did not reach significant levels. Corticosteroid

Table 2. The cell counts (number/mesh) before and after treatment

\begin{tabular}{lccc}
\hline \hline & $\begin{array}{c}\text { Before Treatment } \\
\mathbf{n}: 14\end{array}$ & $\begin{array}{c}\text { After Treatment } \\
\mathbf{n}: 14\end{array}$ & $\begin{array}{c}\mathbf{p} \\
\text { value }\end{array}$ \\
\hline Monocyte & $0.61(0.29-1.01)$ & $0.38(0.29-0.64)$ & 0.140 \\
Macrophage & $1.31(1.00-2.26)$ & $0.91(0.43-1.09)$ & 0.022 \\
Fibroblast & $1.77(0.77-2.14)$ & $1.11(0.58-1.79)$ & 0.109 \\
Neutrophil & $0.15(0-0.97)$ & $0.26(0-0.52)$ & 0.087 \\
Lymphocyte & $0.57(0.44-0.77)$ & $0.29(0.20-0.56)$ & 0.035 \\
Eosinophil & 0 & 0 & - \\
Basophil & 0 & 0 & - \\
\hline Dan & 0 & 0
\end{tabular}

Data were expressed as median (IQR-interquartile range). Statistical analysis could not be performed between groups due to low number of eosinophils and basophils
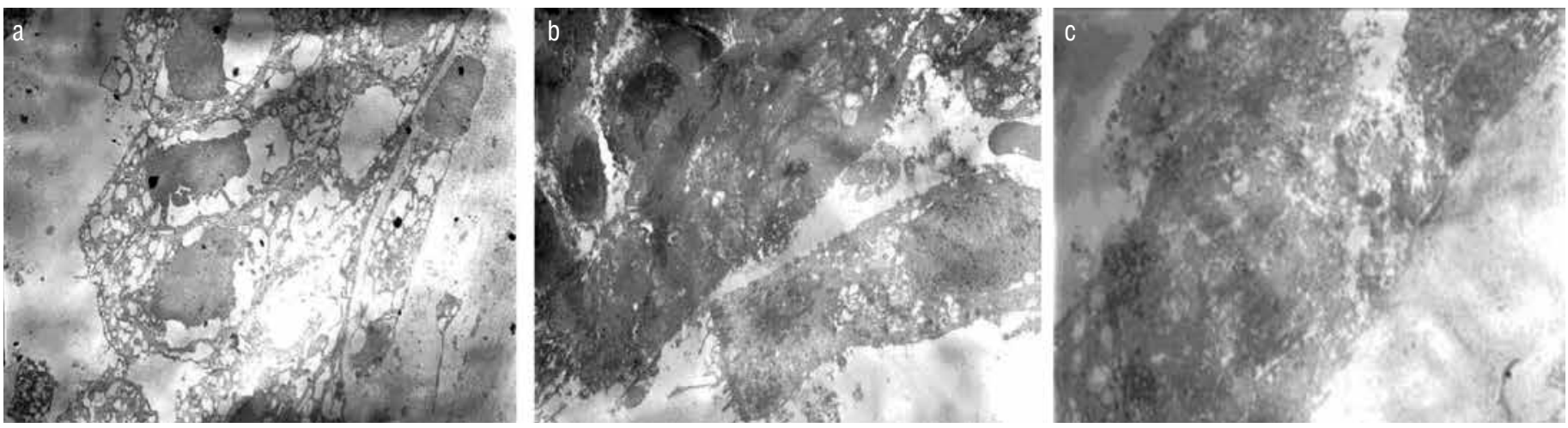

Figure 1. Transmission electron microscopic images illustrating the sections before treatment, $x 2500$ 

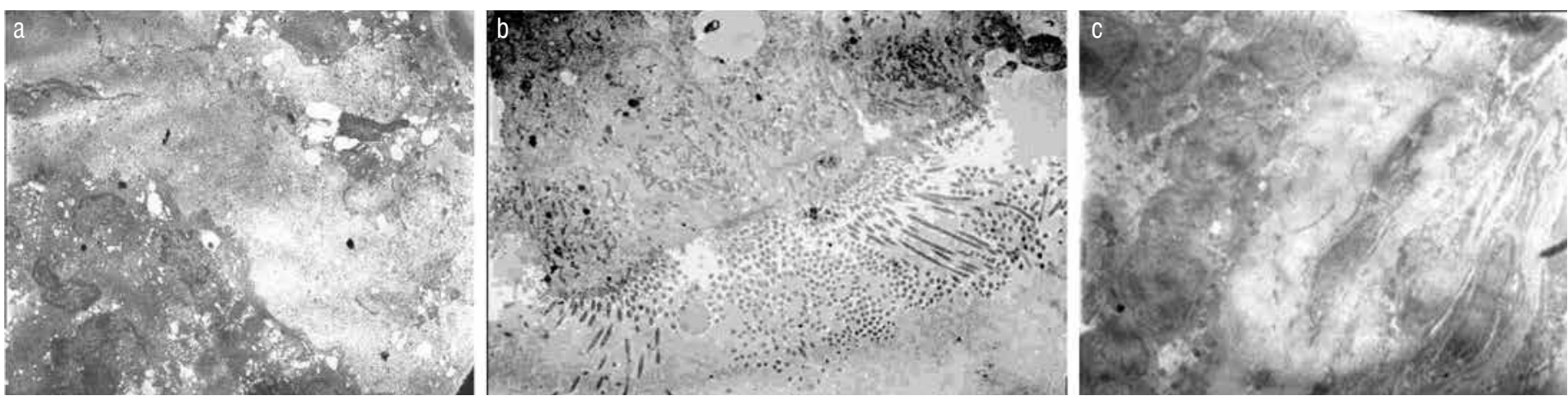

Figure 2. Transmission electron microscopic images illustrating the sections after treatment, $x 2500$.

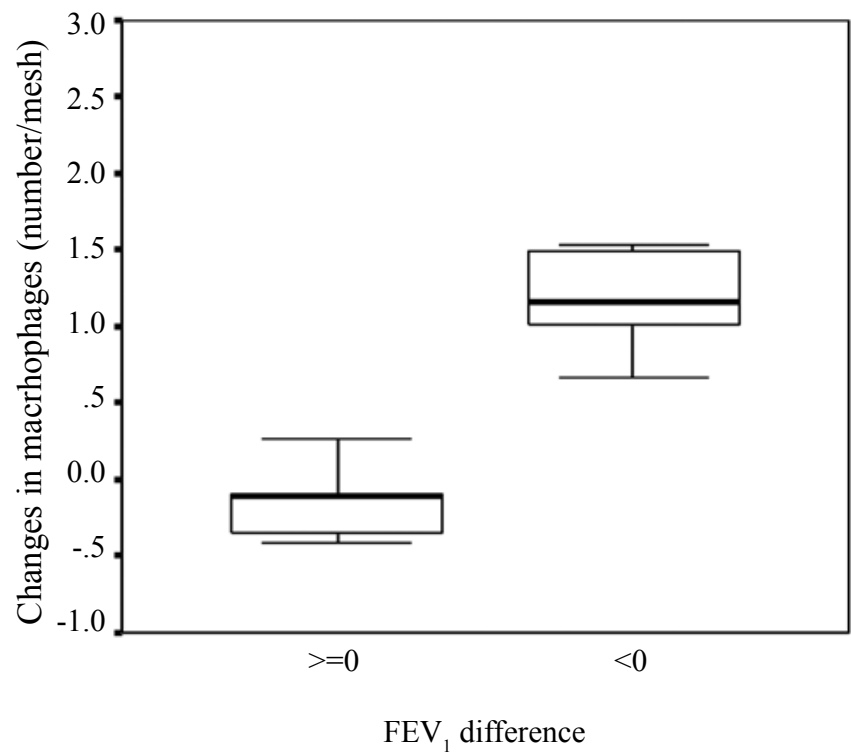

Figure 3. Boxplot showing association between changes in macrophages (number/mesh) and FEV difference $(p<0.05)$.

The boundaries of each box represents the interquartile range $\left(25^{\text {th }}-75^{\text {th }}\right.$ centiles), the horizontal lines inside the boxes represent the median and the error bars outside the boxes represent the $95 \%$ confidence intervals of the mean.

treatment might have led to inhibition of neutrophil apoptosis and prolongation of their survival (14).

The increased thickness of the reticular basal membrane appears as the feature of asthma in the literature $(15,16)$. Several studies reported basal membrane thickness in normal ranges in patients with COPD $(5,11)$. Rutgers et al. (17) observed no difference in the thickness of reticular basal membrane of normal subjects and patients with COPD. Nevertheless, baseline samples of our patient population showed remarkably increased thickness of basal membrane in accordance with the Dutch hypothesis proposing that COPD and asthma were not distinct processes (18). Chanez et al. (19) defined an increased thickness of reticular basal membrane in patients who subsequently responded well to the oral steroid therapy. Conformably, the authors concluded also that it was difficult to define COPD and asthma as separate disorders (19). One of the exciting points of our results was that inhaled corticosteroid therapy resulted in a sig- nificant reduction in basal membrane thickness in patients with COPD. All these findings of our study might support the anti-inflammatory properties of inhaled corticosteroid therapy in patients with COPD. Distinctively, in the presented study, corticosteroid therapy resulted in tidy string epithelial cells having nuclei with regular contours; a reduction in epithelial edema and intracytoplasmic vacuoles compared to baseline samples. In the literature, epithelial cell fragility along with edema were again the expected properties of asthma (15). Gizycki et al. (5) and Hattotuwa et al. (11) determined intact epithelial structures in their earlier studies including patients with COPD. Our results at this point could suggest that decreased inflammation might give rise to a decrease in edema and cell fragility supporting the correlation between intraepithelial edema and inflammation previously shown by Polosukhin (16).

The impairment of mucociliary clearance is one of the main factors that causes chronic bronchial system diseases (20). In a study examining the patients with chronic bronchitis, the most common findings were determined as hyperplasia of goblet cells and the damage of cilliary structures (16). Our findings were in acordance with these results. We observed a significant increase in the number of ciliary structures and a decrease in the number of goblet cells with inhaled steroid treatment.

Inhaled corticosteroid therapy revealed significant improvements in spirometric test results, except the FVC in the presented study. The improvement in the $\mathrm{FEV}_{1}$ value with inhaled corticosteroids were reported in previous studies as well $(12,13,21)$. Inversely, Burge et al. (22) demonstrated no alteration in yearly loss of $\mathrm{FEV}_{1}$ value during three years of $\mathrm{FP}$ treatment in COPD patients. Nevertheless, the number of attacks was reported significantly diminished in that trial (22). In support, Valk et al. (23) pointed out frequent relapses when inhaled steroid treatment had been terminated. Similar to these reports, none of our patients suffered from acute exacerbation during the treatment period. Trials investigating the effectivity of inhaled steroid treatment evaluated the changes in arterial blood gas analyses besides the spirometric tests and the frequency of attacks $(5,6,24)$. In our study, the alterations in arterial blood gas analyses were not found statistically significant. Inhaled corticosteroids mostly accumulate in central airways while the alveolae are the part of the respiratory system in which gas exchange takes place. Hence, the effective transportation of the medication to this edge compartment might be defective. 
A recent meta-analysis including studies, which evaluated the effects of inhaled corticosteroids in COPD patients with bronchial biopsy samples and bronchoalveolar lavage materials, revealed that inhaled corticosteroids have important immunomodulatory effects in this population (25). The favorable outcomes of our study was in accordance with this result. Furthermore, we documented ultrastructural variations at cellular level by means of electron microscopy. However, in current knowledge, there is still controversy in the utilization of inhaled corticosteroids in patients with COPD (26).

There are some limitations of the study. In particular the small number of the patient population and the the lack of a control group should be considered.

\section{CONCLUSION}

Inhaled corticosteroid therapy showed anti-inflammatory effects at cellular level and this was reflected to the functional parameters as improvement in spirometric test results in patients with COPD.

\section{Conflict of Interest}

No conflict of interest was declared by the authors.

Peer-review: Externally peer-reviewed.

Ethics Committee Approval: Ethics committee approval was received for this study from the ethics committee of Dışkapı Yıldırım Beyazıt Education and Research Hospital, Ankara.

Informed Consent: Written informed consent was obtained from patients who participated in this study.

\section{Author Contributions}

Concept - Ç.P.T., S.A.; Design - Ç.P.T., S.A.; Supervision - S.A.; Funding - Ç.P.T., G.U.O.; Materials - C..P.T., K.M.E.; Data Collection and/or Processing - Ç.P.T., G.U.O.; Analysis and/or Interpretation - C.P.T., S.A., K.M.E.; Literature Review - Ç.P.T., G.U.O.; Writing - Ç.P.T., G.U.O.; Critical Review - S.A., K.M.E.

\section{Çıkar Çatışması}

Yazarlar herhangi bir çıkar çatışması bildirmemişlerdir.

Hakem değerlendirmesi: Dış bağımsız.

Etik Komite Onayı: Bu çalışma için etik komite onayı Dışkapı Yıldırım Beyazıt Eğitim ve Araştırma Hastanesi Yerel Etik Kurulu'ndan alınmıştır.

Hasta Onamı: Yazılı hasta onamı bu çalışmaya katılan hastalardan alınmıştır.

\section{Yazar Katkıları}

Fikir - Ç.P.T., S.A.; Tasarım - Ç.P.T., S.A.; Denetleme - S.A.; Kaynaklar - Ç.P.T., G.U.O.; Malzemeler - Ç.P.T., K.M.E.; Veri toplanması ve/veya işlemesi - Ç.P.T., G.U.O.; Analiz ve/veya yorum - C..P.T., S.A., K.M.E.; Literatür taraması - Ç.P.T., G.U.O.; Yazıyı yazan - Ç.P.T., G.U.O.; Eleştirel İnceleme - S.A., K.M.E.

\section{REFERENCES}

1. Pauwels RA, Buist AS, Calverley PM, Jenkins CR, Hurd SS; GOLD Scientific Committee. Global strategy for the diagnosis, management, and prevention of chronic obstructive pulmonary disease. NHLBI/WHO Global Initiative for Chronic Obstructive Lung Disease (GOLD) Workshop summary. Am J Respir Crit Care Med 2001; 163: 1256-76. [CrossRef]

2. Celli BR, MacNee W; ATS/ERS Task Force. Standards for the diagnosis and treatment of patients with COPD: a summary of the ATS/ ERS position paper. Eur Respir J 2004; 23: 932-46. [CrossRef]

3. Barnes PJ. Small airways in COPD. N Engl J Med 2004; 350: 2635-7. [CrossRef]

4. Jeffery PK. Remodeling in asthma and chronic obstructive lung disease. Am J Respir Crit Care Med 2001; 164: 28-38. [CrossRef]

5. Gizycki MJ, Hattotuwa KL, Barnes N, Jeffery PK. Effects of fluticasone propionate on inflammatory cells in COPD: an ultrastructural examination of endobronchial biopsy tissue. Thorax 2002; 57: 799-803. [CrossRef]

6. Yang IA, Clarke MS, Sim EH, Fong KM. Inhaled corticosteroids for stable chronic obstructive pulmonary disease. Cochrane Database Syst Rev 2012; 7: CD002991.

7. Baraldo S, Turato G, Badin C, Bazzan E, Beghé B, Zuin R, et al. Neutrophilic infiltration within the airway smooth muscle in patients with COPD. Thorax 2004; 59: 308-12. [CrossRef]

8. Bourbeau J, Christodoulopoulos P, Maltais F, Yamauchi Y, Olivenstein R, Hamid Q. Effect of salmeterol/fluticasone propionate on airway inflammation in COPD: a randomised controlled trial. Tho$\operatorname{rax} 2007 ; 62:$ 938-43. [CrossRef]

9. Grashoff WF, Sont JK, Sterk PJ, Hiemstra PS, de Boer WI, Stolk J, et al. Chronic obstructive pulmonary disease: role of bronchiolar mast cells and macrophages. Am J Pathol 1997; 151: 1785-90.

10. Lams BE, Sousa AR, Rees PJ, Lee TH. Subepithelial immunopathology of the large airways in smokers with and without chronic obstructive pulmonary disease. Eur Respir J 2000; 15: 512-6. [CrossRef]

11. Hattotuwa KL, Gizycki MJ, Ansari TW, Jeffery PK, Barnes NC. The effects of inhaled fluticasone on airway inflammation in chronic obstructive pulmonary disease: a double-blind, placebo-controlled biopsy study. Am J Respir Crit Care Med 2002; 165: 1592-6. [CrossRef]

12. Reid DW, Wen Y, Johns DP, Williams TJ, Ward C, Walters EH. Bronchodilator reversibility, airway eosinophilia and anti-inflammatory effects of inhaled fluticasone in COPD are not related. Respirology 2008; 13: 799-809. [CrossRef]

13. Barnes NC, Qiu YS, Pavord ID, Parker D, Davis PA, Zhu J, et al. Antiinflammatory effects of salmeterol/fluticasone propionate in chronic obstructive lung disease. Am J Respir Crit Care Med 2006; 173: 736-43. [CrossRef]

14. Shapiro SD. The macrophage in chronic obstructive pulmonary disease. Am J Respir Crit Care Med 1999; 160: 29-32. [CrossRef]

15. Cox G, Whitehead L, Dolovich M, Jordana M, Gauldie J, Newhouse MT. A randomized controlled trial on the effect of inhaled corticosteroids on airways inflammation in adult cigarette smokers. Chest 1999; 115: 1271-7. [CrossRef]

16. Polosukhin VV. Ultrastructural of the bronchial epithelium in chronic inflammation. Ultrastruct Pathol 2001; 25: 119-28. [CrossRef]

17. Rutgers SR, Postma DS, ten Hacken NH, Kauffman HF, van Der Mark TW, Koëter GH, et al. Ongoing airway inflammation in patients with COPD who do not currently smoke. Thorax 2000; 55: 12-8. [CrossRef]

18. Bleecker ER. Similarities and differences in asthma and COPD. The Dutch hypothesis. Chest 2004; 126: 93-5. [CrossRef] 
19. Chanez P, Vignola AM, O'Shaugnessy T, Enander I, Li D, Jeffery PK, et al. Corticosteroid reversibility in COPD is related to features of asthma. Am J Respir Crit Care Med 1997; 155: 1529-34. [CrossRef]

20. Wanner A. The role of mucus in chronic obstructive pulmonary disease. Chest 1990; 97: 11-5. [CrossRef]

21. Lapperre TS, Snoeck-Stroband JB, Gosman MM, Jansen DF, van Schadewijk A, Thiadens HA, et al. Effect of fluticasone with and without salmeterol on pulmonary outcomes in chronic obstructive pulmonary disease: a randomized trial. Ann Intern Med 2009; 151: 517-27. [CrossRef]

22. Burge PS, Calverley PMA, Jones PW, Spencer S, Anderson JA. Prednisolone response in patients with chronic obstructive pulmonary disease: results form the ISOLDE study. Thorax 2003; 58: 654-8. [CrossRef]
23. van der Valk P, Monninkhof E, van der Palen J, Zielhuis G, van Herwaarden C. Effect of discontinuation of inhaled corticosteroids in patients with chronic obstructive pulmonary disease: the COPE study. Am J Respir Crit Care Med 2002; 166: 1358-63. [CrossRef]

24. van Grunsven PM, van Schayck CP, Derenne JP, Kerstjens HA, Renkema TE, Postma DS, et al. Long term effects of inhaled corticosteroids in chronic obstructive pulmonary disease: a meta-analysis. Thorax 1999; 54: 7-14. [CrossRef]

25. Jen R, Rennard SI, Sin DD. Effects of inhaled corticosteroids on airway inflammation in chronic obstructive pulmonary disease: a systematic review and meta-analysis. Int J Chron Obstruct Pulmon Dis 2012; 7: 587-95.

26. Rabe KF, Wedzicha JA. Controversies in treatment of chronic obstructive pulmonary disease. Lancet 2011; 10: 1038-47. [CrossRef] 